most objectionable of all, student participation on faculty hiring and promotions boards.

The county's current population of 68 million is expected to reach 70 million by the year 2000 , and to surpass 100 million by 2020. Education is a burden that the public sector is not able to carry satisfactorily. Nearly 1.8 million students now participate in various tertiarylevel institutions (two-year colleges, four-year, and comprehensive and technical universities) at 350 public and 950 private colleges and universities. Private higher education institutions already enroll approximately 79 percent of the student population, with state schools taking care of only 21 percent.

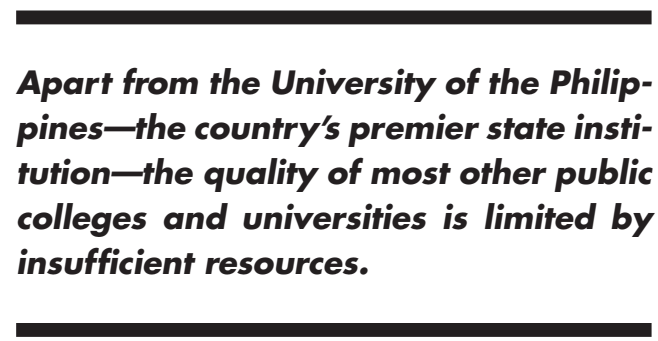

Apart from the University of the Philippines-the country's premier state institution-the quality of most other public colleges and universities is limited by insufficient resources. Most of the best schools are private ones. Thus, the private sector is expected to play a pivotal role in the development and improvement of Philippine higher education.

The House Bill has become a political issue as the proponents, looking toward national elections in 1998, are seeking favor with students, who constitute a sizable voting block of young adults. The Philippine constitution considers 18-year-olds as eligible to vote; hence, in a country where two-thirds of the population is 25 years or younger, the youth vote determines the winners.

President Fidel V. Ramos and speaker of the House, Jose de Venecia-himself a candidate for the presidency - recently called for a series of meetings with legislators, students, and college administrators in an effort to iron out differences and reach a compromise on the more objectionable features of the Magna Carta.

The situation is symbolic of what ails Philippine higher education: the politicization of even the internal management of academic life, the blurring of distinctions between learners and teachers, and public ambivalence toward private colleges and universities, which are needed but also resented due to their profit-making orientation as teaching institutions that do little or no research.

\section{Tenure in the United States: 20th Century Relic or Essential Structure for the 21 st Century?}

\section{William G. Tierney}

William G. Tierney is Professor and Director of the Center for Higher Education Policy Analysis at the University of Southern California. Address: School of Education - WPH 701, University of Southern California, Los Angeles, CA 90089-0031. E-mail: <wgtiern@usc.edu>.

$\mathrm{A}$ rguably at no time in this century has tenure in the -United States come under attack as vociferously and consistently as it has over the last few years. Tenure came about in U.S. colleges and universities in large part to protect infringements on academic freedom that occurred at the end of the 19th and the start of the 20th century. Throughout this century critics and protectors of tenure have argued about tenure's effectiveness and import.

I have been involved in two studies over the last four years that deal with faculty productivity and tenure's effectiveness. ${ }^{1}$ The arguments pertaining to tenure revolve around six key issues.

\section{Tenure's Flaws: The Critic's Concerns}

Tenure rigidifies positions, argue some. At a time when an institution needs to reorganize it cannot. Some have said that tenure imposes an inflexible financial burden upon institutions. Academe needs to be nimble, suggest critics, and tenure prohibits that.

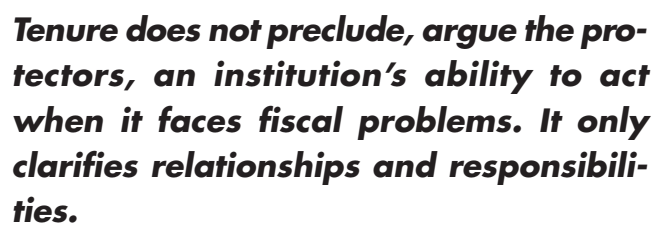

Tenure does not preclude, argue the protectors, an institution's ability to act when it faces fiscal problems. It only clarifies relationships and responsibilities.

It is said that tenure protects unproductive individuals. The assumption is that in business and industry such individuals would be fired. Howard Bowen and Jack Schuster write that "the procedures for ridding the profession of misfits are so arduous and so embarrassing that few administrators are willing to take the time of themselves and the faculty to prosecute the cases. The procedures take on the flavor of a trial for murder." ${ }^{2} \mathrm{I}$ have not been to any institution where someone has pointed to more than two tenure dismissals over the last decade. The critics allege that such a number is too small 
if we are serious about getting rid of dead wood.

Another concern is that tenure actually does the opposite of what it is supposed to do. Rather than enable people to experiment, it makes people risk-averse. Tenure does not move people toward creativity, but rather toward conformity. Assistant professors are socialized to publish articles rather than take risks.

It is argued that tenure does not enable faculty to focus on teaching excellence. State legislatures and the public want faculty to do more teaching. Critics assert that tenure makes such a goal impossible. Tenure rewards research, goes the thinking, and if we want to change priorities then we need to get rid of tenure.

\section{If academic freedom is a central totem of the academy, then we must protect it or risk fundamental redesign.}

Opponents charge that tenure only protects those with tenure. We have an odd system of haves and havenots that creates large cadres of second-class citizens. Again, rather than creating a democratic organizational structure that enables all people to be creative and innovative, it is said, we have a system where senior professors with structured employment contracts control the texture of academic life so that those who do not conform will find themselves in jeopardy.

Finally, critics say that we might have needed tenure to support academic freedom a long time ago, but not today. We are more enlightened and enjoy legal protections. Further, the vast majority of faculty never write or say anything that tests the limits that academic freedom is expected to protect. Increasingly, faculty surveys report that faculty do not feel the need for a protection of their academic freedom-either it is not needed for them, or they are not concerned.

\section{Tenure's Strengths: The Defenders Respond}

The problems attributed to tenure have received vigorous rebuttal from tenure's protectors. Tenure does not preclude, they argue, an institution's ability to act when it faces fiscal problems. It only clarifies relationships and responsibilities. Numerous institutions have retrenched over the last generation, letting tenured faculty go in the process.

While most individuals admit that unproductive faculty exist in the academy and some of them have tenure, there are no data indicating that colleges and universities are more unproductive than other organi- zations. Henry Rosovsky, for example, has estimated that unproductive faculty make up under 2 percent of an institution's faculty. ${ }^{3}$ Can a business or other organization boast of a better level? Unproductive personnel are a problem that every business faces; to blame this on tenure is unwarranted.

One of the key concerns of the protectors of tenure is that critics rely on anecdote in order to attack a perceived problem. Experimentation may be a problem for some junior faculty coming up for tenure. However, there are numerous individuals who have tenure and have developed breakthroughs in multiple areas because they had the time that tenure afforded for scientific or scholarly work without the fear that they had to produce. Certainly getting rid of tenure will not increase experimentation of the kind necessary for intellectual thought.

Advocates reserve their toughest responses for those who propose that the untenured are not protected and that academic freedom no longer needs protection. The fact that few faculty test the principles of academic freedom today does not mean that the protections are no longer needed. There are still plentiful examples that highlight abridgments of academic freedom in late 20th century America. An analogy is apt: simply because most U.S. citizens do not test the limits of free speech, we do not say we should abolish the First Amendment. If academic freedom is a central totem of the academy, then we must protect it or risk fundamental redesign. And although it is true that tenure does not provide the untenured the legal protections it affords those with tenure, surely getting rid of tenure is not the solution. If anything, those with tenure have an obligation to ensure that their nontenured colleagues are protected. The tenured act as guardians of the institution; they are not simply beneficiaries of tenure.

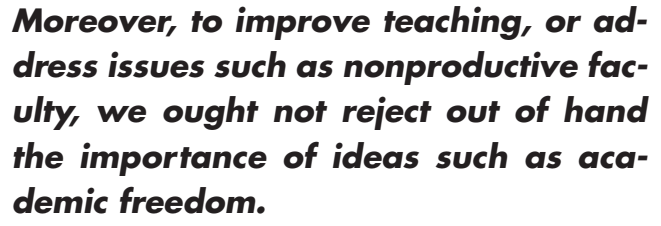

\section{Whither Tenure?}

One criticism I mentioned above pertains to teaching. Presumably the system of tenure does not help us improve teaching. Indeed, relatively new ideas, such as posttenure review, quite often have the opposite effect. If the requirements and framework for tenure remain 
the same, then the implementation of a posttenure review system will only focus more attention on research, as opposed to teaching.

Moreover, to improve teaching, or address issues such as nonproductive faculty, we ought not reject out of hand the importance of ideas such as academic freedom. It seems wrong-headed to suggest that we must give up the cherished value of academic freedom to help make the academy more efficient. And I have seen no work that proposes alternative structures that will provide as rigorous a support of academic freedom as does tenure. ${ }^{4}$ At the same time, we also must recognize the fiscal and productivity-related issues that currently confront the academy. What should we do?

One step is to move the debate away from the pros and cons of tenure. If issues such as productivity are a concern, we should address them alone-just as we would in business and industry. Tenure is a structure that is governed and defined by faculty and administrators-it can change according to communal desire.

A second step is to consider ways to implement performance reviews that do not bring into question whether tenure should or should not stay. Instead, we might develop a system that enables a professor to talk about the kind of work he or she intends to do, and allows the faculty to assess these plans to ensure that all individuals are able to make a contribution to their academic communities while we still maintain an adherence to academic freedom and the tenure system. The best of both worlds - the maintenance of academic freedom and a more productive academy-are surely possible if we put our minds and hearts to it.

\section{Notes}

1. William G. Tierney and Estela M. Bensimon, Promotion and Tenure, Community and Socialization in Academe (Albany, NY: SUNY, 1996); William G. Tierney, ed., The Responsive University: Restructuring for High Performance (Baltimore, Md: Johns Hopkins University Press, 1998).

2. Howard Bowen and Jack Schuster, American Professors: A National Resource Imperiled (New York: Oxford University Press, 1986), 243.

3. Henry Rosovsky, The University: An Owner's Manual (New York: W. W. Norton, 1990), 211.

4. Erwin Chemerinsky, American Behavioral Scientist (February 1998): 640-53.

\section{Internet Resource}

For more information on international issues in higher education, visit the Center's web site, located at:

http://www.bc.edu/bc_org/avp/soe/cihe/

\section{A Presidential Perspective from Japan}

\section{Yoshiiaki Obara}

Yoshiiaki Obara is president of Tamagawa University. Address: 6-1-1 Tamagawa Gakuen, Machida, Tokyo 194, Japan.

\begin{abstract}
A university president should perhaps keep quiet about problems his institution faces. But it would be a lie to say that no problems exist. Indeed, presidents of privatesector institutions of higher education in Japan face a range of challenging issues.

Some issues relate to the size of an institution. Private institutions in Japan range in size from 1,000 to 100,000 students. A president of a large university, having to preside over campus-wide faculty meetings, may long for a family atmosphere similar to faculty meetings at a small college. Some private colleges have but a single school or faculty. A president of such a college may feel at a disadvantage in the competition to attract students. A president of an engineering college has to work hard to keep up with ever-changing technologies, while one at a humanities college can sit back and relax.
\end{abstract}

\section{Many institutions today are struggling with the dichotomy involving quality or quantity.}

Some private institutions enjoy a long history and elite status much like that of the national universities. Some private schools have national reputations, while others are known only in their own region. And finally, there are the many so-called "train station box lunch" colleges that lack academic legitimacy. These last two types of institutions have a much harder job in reaching and recruiting students.

\section{The Quality/Quantity Dichotomy}

Many institutions today are struggling with the dichotomy involving quality or quantity. Quality refers to admitting students who have the scholastic aptitude, study habits, and clear academic and career goals that qualify them for higher education. For such students, college or university should be an opportunity for academic higher learning and a chance to open up one's career possibilities. But it certainly should not be a time for $\mathrm{R} \& \mathrm{R}$, a reward for having studied hard from the 4th to the 12th grade and having passed the difficult entrance exam. It is a president's responsibility to provide a quality academic environment (faculty, building, and 